DOI No: http://dx.doi.org/10.29228/Joh43153

Makale Türü: Araştırma makalesi

Geliş Tarihi: 23.04.2020

Kabul Tarihi: 17.05.2020

On-line Yayın: 25.06.2020
Article Type: Research article

Submitted: 23.04 .2020

Accepted: 17.05 .2020

Published Online: 25.06.2020

Atıf Bilgisi / Reference Information

Ulukan, H. (2020). Investigation of The Leadership Levels of University Students Who Do Sports and Non-Sports According to Different Variables: The Case of Isparta. journal of History School, 46, 1910-1928.

\title{
INVESTIGATION OF THE LEADERSHIP LEVELS OF STUDENTS OF THE SPORT SCIENCE WHO DOING ACTIVE SPORTS AND NON ACTIVE SPORTS ACCORDING TO DIFFERENT VARIABLES: THE CASE OF ISPARTA ${ }^{1}$
}

\author{
Hasan ULUKAN ${ }^{2}$
}

\begin{abstract}
In this study, it is aimed to investigate the leadership orientation of students of sports science who do active sports and do not do active sports at Suleyman Demirel university according to different variables. The data of the study were collected between November 12 and December 24, 2019. This research participated in 177 students, 73 females, and 104 males. As the data collection tool; It was used The Leadership Orientations Scale developed by Bolman and Deal (1990) and adapted to Turkish by Dereli (2003). Parametric tests were used due to the normal distribution of the data. When the data obtained were examined, it is seen that the scale had significant differences in terms of transformational leadership, charismatic leadership sub-dimensions, and gender. It was observed a significant difference in transformational leadership and charismatic leadership according to active doing sports and sports branch. Moreover, it was observed that there was no statistically significant difference in terms of the sub-dimensions of the leadership scale and place of residence and age variables. However, it was determined that the level of leadership of the people living in the villages is higher than those living
\end{abstract}

\footnotetext{
${ }^{1} \mathrm{Bu}$ çalışmanın verileri $12 \mathrm{Kasım}-24$ Aralık 2019 tarihleri arasında toplanmıştır.

${ }^{2}$ Dr. Öğretim Üyesi, Aydın Adnan Menderes Üniversitesi, Spor Bilimleri Fakültesi, Spor Yöneticiliği Anabilim Dalı, hasan.ulukan@adu.edu.tr, Orcid: 0000-0002-2313-201X
} 
Investigation of The Leadership Levels of University Students Who Do Sports and NonSports According to Different Variables: The Case of Isparta.

in the city. Also, it was concluded that the students active doing sports at the university showed above medium level leadership tendency and was at a well-accepted level.

Keywords: Sports Science, Student, Leadership, Leadership Orientation.

\section{Aktif Spor Yapan ve Aktif Spor Yapmayan Spor Bilimleri Öğrencilerinin Liderlik Düzeylerinin Farklı Değișkenlere Göre İncelenmesi: Isparta Örneği}

\section{$\ddot{\mathbf{O z}}$}

Bu çalışmada Süleyman Demirel üniversitesinde aktif spor yapan ve aktif spor yapmayan spor bilimleri öğrencilerin liderlik yönelimlerinin farklı değişkenlere göre incelenmesi amaçlanmıştır. Çalışmanın verileri 12 Kasım-24 Aralık 2019 tarihleri arasında toplanmıştır. Araştırmaya Isparta'da 73 kadın ve 104 erkek olmak üzere 177 öğrenci katılmıştır. Veri toplama aracı olarak Bolman ve Deal (1990) tarafindan geliştirilen, Dereli (2003) tarafindan Türkçe'ye uyarlanan Liderlik Yönelimleri Ölçeği kullanılmıştır. Verilerin normal dağılımı sebebiyle parametrik testler kullanılmıștır. Elde edilen veriler incelendiğinde ölçeğin dönüşümsel liderlik, karizmatik liderlik alt boyutları ile cinsiyete göre anlamlı farkl11ıklar olduğu görülmüştür. Spor yapma ve spor branşına göre dönüşümcü liderlik ve karizmatik liderlikte anlamlı bir fark olduğu gözlenmiştir. Ancak liderlik ölçeğinin alt boyutları ile ikamet edilen yer ve yaş değişkenlerine göre istatistiksel olarak anlamlı bir fark olmadığ 1 gözlenmiştir. Ancak köylerde yaşayanların liderlik düzeyinin şehirde yaşayanlardan daha yüksek olduğu belirlenmiştir. Ayrıca Üniversitede spor yapan öğrencilerin orta düzeyin üstünde liderlik eğilimleri gösterdikleri ve kabul edilen bir düzeyde oldukları sonucuna varılmıştır.

Anahtar Kelimeler: Spor Bilimleri, Öğrenci, Liderlik, Liderlik Yönelimleri.

\section{INTRODUCTION}

The leader in the dictionary is the person, leader, chef, and the realm (TDK, 2019), who, due to his strength, reputation and social place, shows the ability to change and manage the attitudes, behaviors, and activities of the cluster or society that he is associated within certain time and situations. Leader; It is the person who sets an example to his environment with his moral understanding, style and behavior, and provides a model that he can identify with, and provides an environment open to change, innovation, and creativity (Baltaş, 2012). 
The concept of leadership is as old as human history. Leadership has shown itself in every society, every organization, in short, every part of life. Humans are social creatures living in groups as well as being leaders who need hierarchical loyalty with the leader who will manage the groups they create and lead them to their goals (Robbins S. 1984). Drucker (2000), in the foreword of the book "The Leader of the Future", expressed the concept of the effective leader as the person who made the right things with the easiest expression (Hesselbein, Goldsmith and Beckhard, 2000). Leadership is an extremely important, universal, human, and social phenomenon that is the case in every environment where human communities and organizations exist (Daft, 2001). While a leader is a person who motivates and influences organizational people towards a goal and affects and guides organizational goals, leadership is the process of influencing and guiding others' activities to achieve certain individual or organizational goals under existing conditions and situations (Koçel, 2001).

Nowadays, only your motoric skills and abilities are not enough to be a good athlete. Athletes must be able to keep up with all kinds of environments and conditions to stay on top levels and stay there, protecting their discipline and motivation by resisting the pressures that will occur. It is not an easy thing to accomplish these by themselves. They need a team to support them outside the competition. Doing individual sports or team sports does not change the need for this team. For example, in tennis, which is an individual sport, there is a large team behind the athletes. The leader of this team is a coach in every sport. The fact that coaches develop their athletes in the field of physical training does not make them a successful leader. They should be fair as a leader, and a sense of trust should be developed with their athletes. When the conditions are bad, the athlete should feel that he has a good leader, that is, the coach. The leader has defined as an educator with the power to influence individuals in an organization or group in line with a specific goal (Baltaş, 2007). The main goal of leadership is to give people the confidence to express themselves, to adapt to different situations, to gain the ability to ask and question. Achieving this is through falling. For this reason, it is necessary to support trend programs that are the basis of reason and science. Today, many reasons require leadership orientation to reach the determined short and long term goals, which should be protected from unwanted movements while giving sports education as in all academic fields of the society (Cengiz and Güllü, 2018). The belief is that management is learned through education and experience, but leadership is inherent in one. While leadership involves processes such as recognizing the opportunities brought by change, interpreting the future, turning their comments into a message and instilling those around them, uniting people around a belief; management is 
Investigation of The Leadership Levels of University Students Who Do Sports and NonSports According to Different Variables: The Case of Isparta.

perceived as a more routine, technical and developing process within the rules (Baltaş, 2016).

It is hoped that it will be possible to contribute to the literature by revealing some variables that will positively affect the performances and personalities of athletes by considering all the relationships described above within the scope of a model, evaluating the relationships between some variables that have not been previously examined, and evaluating the examined variables in a holistic and detailed manner.

\section{Literature Review}

When we ask a question, "What is a leader?", We see that people say: "A military commander, political party leader or coach". Studies with various definitions in the local and foreign literature on the subject of leadership and leadership are frequently seen. Leadership (leadership) and leader are very old concepts. When these studies are analyzed, it is seen that no definition of leadership is agreed upon. Researchers have defined the definition of the leader according to their perspective and their field. Some leader definitions in this context are given below.

The leader is the person who has made the potential forces of the people in the team or organization he leads, suitable for the organization, and can actively use these forces (Eren, 2013). Leadership is the art of getting the job done by leaving them around (Darbaz, 2004). According to Ertürk (1998), leadership is the process of influencing those who are together in the light of common goals to fulfill these goals. According to Eren (2012), leadership is the sum of the ability and ingenuity to unite a group of people in line with the determined goals and to mobilize that ready group for these goals. Leadership is an extremely important, universal, human, and social phenomenon, which is at stake in any environment where human communities and organizations are present. Comprehensive research, reviews, and similar studies on leaders and leadership are concrete indicators of the importance attached to the subject. The definitions of the authors who define the leadership are also very diverse depending on the world view, the field they work in, their knowledge, and the feature they want to emphasize. In fact, since leadership, or leadership, is a semantically (semantically) abstract concept, there are as many leadership/leadership definitions as the number of people and it differs According to conditions, time, and situations (Biçer, 2008). In another definition, leadership is important in almost all areas, but this is more important in the sports environment. Sports organizations are different from other environments. Here, the leader takes an active role in influencing the group to pre-determined goals. Leaders engage in long-term relationships with athletes 


\section{Hasan ULUKAN}

and share many emotions such as success, magnificence, sadness, frustration, pain, joy with athletes and create a special climate atmosphere in the team (Koruç, 1995). Leadership is related to the concept of power. In general terms, power is defined as the ability to influence and direct others (Karkin, 2004), while leadership is defined as influencing and directing the activities of others to achieve specific personal and group goals under certain conditions (Koçel, 2001).

Leadership occurs through the interaction of people, is the process of influencing others, and is used to direct the group to specified goals. Leadership is the ability to influence others to achieve predetermined goals (Daft, 1997). People admire their personalities as if the leader has unusual characteristics (Brooks, 2006). Another definition; "It is the person who expresses the common thoughts and desires that can be felt by the leader group members but has not been clarified in the form of a goal that can be adopted and activates the potential powers of the group members (Eren, 2016).

As seen in the definitions, influencing is important in leadership. Also, leadership refers to the process of influencing the group towards achieving its goals, while the leader refers to the person who can influence people and have managerial authority in this process. Leadership, the leader of the ability to persuade people towards specific goals, is also the person who brings together the group members and motivates them for group goals. As a result, the strength of leadership is proportional to the acceptance seen by the managed group. In this acceptance; The belief that the leader will be effective in meeting the needs of the group plays an important role. One of the main functions of the leader is to be able to solve this conflict positively when its needs and the group's needs conflict (Özdemir, 2003).

\section{METHOD}

\section{Research Model}

The research is a study in the survey model. Survey models are research approaches aiming to describe a situation that exists in the past or still as it exists. Also, since the differences in terms of gender, age, place of residence, high school, sports, and sports branch are examined in terms of the specified variables, it features the comparative relational survey model (Karasar, 2012).

\section{Universe and Sample}

The fact that the results obtained in the scientific studies contribute to the studies to be carried out is an important clue that reveals the quality of that study. 
Investigation of The Leadership Levels of University Students Who Do Sports and NonSports According to Different Variables: The Case of Isparta.

The results achieved through these tips provide access to holistic information about any field (Karasar, 2016).

The concept defined as the community in which the research results are interpreted is called the universe (Büyüköztürk et al., 2012). In this context, the universe of the research is students who study at Süleyman Demirel University. The group that takes place in the universe and is researched and generalized to the universe is called the sample (Büyüköztürk, 2017). The data of the study were collected between November 12 and December 24, 2019. The sample of the study consists of 177 students determined by using the "Simple random sampling" method among the students who do and do not do sports at Süleyman Demirel University. Explanatory information according to the variables of gender, age, place of residence, active doing sports, and sports branch of the students participating in the research are given in the tables below.

Frequency and percentage distributions of the variables, gender, age, place of residence, high school, sports status, and sports branch of the individuals participating in the study are shown in table 1.

\section{Table 1}

Students of Sport Sciences' Frequency and Percentage Distribution across the Variables.

\begin{tabular}{llcc}
\hline Variables & Groups & N & \% \\
\hline \multirow{2}{*}{ Gender } & Female & 73 & 41,2 \\
& Male & 104 & 58,8 \\
\multirow{4}{*}{ Age } & $18-20$ & 56 & 31,6 \\
& $21-23$ & 86 & 48,6 \\
& $24-26$ & 22 & 12,4 \\
\multirow{4}{*}{ Place of Residence } & City and over & 13 & 7,3 \\
& Cetropolis & 79 & 44,6 \\
\multirow{4}{*}{ Active Doing Sports } & 61 & 34,5 \\
& County & 27 & 15,3 \\
Type of Sport & Village & 10 & 5,6 \\
& No & 100 & 56,5 \\
& Team Sports & 77 & 43,5 \\
& Individual Sports & 72 & 40,7 \\
& None of Them & 28 & 15,8 \\
\hline
\end{tabular}

As can be seen in Table 1, a total of 177 students, $41.2 \%$ female (female who doing active sports 26 , female who do not do active sports 47 ) and $58.8 \%$ 


\section{Hasan ULUKAN}

male (male who doing active sports 74, the male who do not do active sports 30 ), participated in the study. The majority of the students $(48.6 \%)$ according to the age variable are between 21-23 years old. It was observed that the majority of the participants $(44.6 \%)$ were metropolitan. When the variable of active doing sports of individuals was examined (56.5\%), it was found to be active in doing sport. Besides, when the status of the sport type of individuals was examined, it was determined that the highest participation was the students who made team sports $(40.7 \%)$.

\section{Data Collection Tools}

Personal Information Form: This personal information form developed by the researchers, some items give information about gender, age, place of residence, active doing sports, and sports branch of the participants.

Leadership Orientations Scale: This scale was developed by Bolman and Deal (1990) to evaluate students' leadership traits. The validity and reliability study of the scale was carried out by Dereli in 2003. This scale developed consists of three parts: leadership behaviors, leadership style, and the individual's perceptions as a manager and leader. In this study, leadership behaviors, the first part of the scale, were used. The department, which evaluates leadership behaviors, consists of 5 Likert-type, 4 sub-dimensions, and 32 items. Minimum 8 points and a maximum of 40 points can be obtained from each dimension. The high score obtained from the dimensions of the scale shows that the related leadership characteristics of the person always show; the low score indicates that it has never displayed its leadership qualities (Dereli, 2003; McArdle, 2008). Cronbach Alpha's internal consistency coefficient was calculated as 0.90. Sample items related to the sub-dimensions of the scale are given below.

\section{Table 2}

Sample Items Found in Leadership Orientations Scale

\begin{tabular}{lcl}
\hline Dimension & Item no & Sample items \\
\hline $\begin{array}{l}\text { Human Resource } \\
\text { Leadership }\end{array}$ & 2 & $\begin{array}{l}\text { I support other people and show interest in their } \\
\text { problems. }\end{array}$ \\
$\begin{array}{l}\text { Structural Leadership } \\
\text { I emphasize careful planning and the importance of } \\
\text { completing the planned works on time. }\end{array}$ \\
$\begin{array}{l}\text { Leadership } \\
\text { Charismatic } \\
\text { Leadership }\end{array}$ & 11 & $\begin{array}{l}\text { My convincing ability is good and I am impressive. } \\
\text { I am a model / exemplary manager who reflects the } \\
\text { corporate values and goals for the people around me. }\end{array}$ \\
\hline
\end{tabular}


Investigation of The Leadership Levels of University Students Who Do Sports and NonSports According to Different Variables: The Case of Isparta.

\section{Data Analysis}

The collected data were analyzed with SPSS (Statistical Package for the Social Sciences) Version 25. Firstly, the normality of distribution was checked to determine the statistical tests to be run. The Kurtosis values for both of the scale and their sub-dimensions were found to be varying between +2 and -1 while their Skewness values were found to be varying between +1 and -1 . According to Huck (2008), these values showed that the data collected in the current study were within the borders of normal distribution (as cited in Secer, 2015). Thus, in the analysis of the collected data, frequencies, percentages, independent samples ttest, and one-way variance analysis (ANOVA) were used.

\section{FINDINGS}

In this section, the findings of the current study are presented within the framework of sub-problems. Findings of the first sub-problem of the study "What is the level of leadership orientation of students of sports sciences'?" It is given in Table 3.

\section{Table 3}

Students of Sport Sciences' Levels of Leadership Orientation

\begin{tabular}{lccc}
\hline & $\mathbf{n}$ & $\overline{\mathbf{x}}$ & $\mathbf{S D}$ \\
\hline Structural Leadership & 177 & 31,20 & 4,66 \\
Transformational Leadership & 177 & 29,76 & 5,08 \\
Charismatic Leadership & 177 & 30,20 & 5,55 \\
Leadership Orientations Total & 177 & 123,03 & 18,04 \\
\hline
\end{tabular}

As can be seen in Table 3, the highest score that can be obtained from the 32 -item scale is 160 , and the lowest score is 32 . In this study, the average score of the participants from the entire scale was found as 123.03. In this context, it can be said that the levels of leadership orientation of the students participating in the research are above the middle level ( $\overline{\mathbf{X}}=123,03$; SD: 18.04).

Is there a significant difference in perceptions of Students of Sport Sciences' leadership orientation levels according to gender? Independent sample t-test results are given in Table 4 to find an answer to the subproblem. 


\section{Hasan ULUKAN}

\section{Table 4}

Results of the t-Test Conducted to Students of Sport Sciences' Leadership Orientation Levels According to Gender Variable

\begin{tabular}{|c|c|c|c|c|c|c|c|}
\hline & Gender & $\mathbf{n}$ & $\overline{\mathbf{x}}$ & SD & df & $\mathbf{t}$ & $\mathbf{p}$ \\
\hline \multirow{3}{*}{$\begin{array}{l}\text { Human Resource } \\
\text { Leadership }\end{array}$} & Female & 73 & 31.69 & 5.55 & \multirow{3}{*}{175} & \multirow{3}{*}{-.359} & \multirow{3}{*}{.720} \\
\hline & & & & & & & \\
\hline & Male & 104 & 31.98 & 4.83 & & & \\
\hline \multirow{3}{*}{ Structural Leadership } & Female & 73 & 30.61 & 4.46 & \multirow{3}{*}{175} & \multirow{3}{*}{-1.421} & \multirow{3}{*}{.157} \\
\hline & & & & & & & \\
\hline & Male & 104 & 31.62 & 4.76 & & & \\
\hline \multirow{3}{*}{$\begin{array}{l}\text { Transformational } \\
\text { Leadership }\end{array}$} & Female & 73 & 28.65 & 5.15 & \multirow{3}{*}{175} & \multirow{3}{*}{-2.457} & \multirow{3}{*}{.015} \\
\hline & & & & & & & \\
\hline & Male & 104 & 30.53 & 4.91 & & & \\
\hline \multirow{3}{*}{ Charismatic Leadership } & Female & 73 & 28.82 & 5.57 & \multirow{3}{*}{175} & \multirow{3}{*}{-2.825} & \multirow{3}{*}{.005} \\
\hline & & & & & & & \\
\hline & Male & 104 & 31.17 & 5.35 & & & \\
\hline \multirow{2}{*}{$\begin{array}{l}\text { Leadership Orientations } \\
\text { Total }\end{array}$} & Female & 73 & 119.79 & 18.07 & \multirow{2}{*}{175} & \multirow{2}{*}{-2.022} & \multirow{2}{*}{.045} \\
\hline & Male & 104 & 125.31 & 17.76 & & & \\
\hline
\end{tabular}

When Independent Samples t-Test in Table 4 is examined, "Transformational Leadership" $\left[\mathrm{t}_{(175)}=-2.457, \mathrm{p}<, 05\right]$, "Charismatic Leadership" $\left[\mathrm{t}_{(175)}=-2.825, \mathrm{p}<, 05\right]$ and at the whole scale $\left[\mathrm{t}_{(175)}=-2.022, \mathrm{p}<, 05\right]$ significant differences were detected. According to the gender variable, it was determined that the participants were in favor of men in the sub-dimensions of leadership orientations and the scale.

Students of sports sciences' is there a significant difference in perceptions of leadership orientation levels according to the age variable? One-way analysis of variance (ANOVA) results is given in Table 5 to find an answer to the subproblem. 
Investigation of The Leadership Levels of University Students Who Do Sports and NonSports According to Different Variables: The Case of Isparta.

\section{Table 5}

Results of the One-way Variance Analysis Conducted to Students of Sport Sciences" Leadership Orientation Levels According to Age Variable

\begin{tabular}{|c|c|c|c|c|c|c|c|}
\hline & Age & $\mathbf{n}$ & $\overline{\mathbf{x}}$ & SD & df & $\mathbf{F}$ & $\mathbf{p}$ \\
\hline \multirow{6}{*}{$\begin{array}{l}\text { Human Resource } \\
\text { Leadership }\end{array}$} & $18-20$ & 56 & 31.44 & 5.72 & \multirow{5}{*}{$3-173$} & \multirow{5}{*}{.196} & \multirow{5}{*}{.899} \\
\hline & $21-23$ & 86 & 32.02 & 5.30 & & & \\
\hline & $24-26$ & 22 & 32.27 & 3.64 & & & \\
\hline & 27 and over & 13 & 31.92 & 3.45 & & & \\
\hline & Total & 177 & 31.86 & 5.13 & & & \\
\hline & $18-20$ & 56 & 31.53 & 4.99 & \multirow{5}{*}{$3-173$} & \multirow{5}{*}{.169} & \multirow{5}{*}{.917} \\
\hline \multirow{4}{*}{ Structural Leadership } & $21-23$ & 86 & 31.00 & 4.56 & & & \\
\hline & $24-26$ & 22 & 31.04 & 4.20 & & & \\
\hline & 27 and over & 13 & 31.46 & 4.97 & & & \\
\hline & Total & 177 & 31.20 & 4.66 & & & \\
\hline \multirow{5}{*}{$\begin{array}{l}\text { Transformational } \\
\text { Leadership }\end{array}$} & $18-20$ & 56 & 29.53 & 4.92 & \multirow{5}{*}{$3-173$} & \multirow{5}{*}{1.739} & \multirow{5}{*}{.161} \\
\hline & $21-23$ & 86 & 29.30 & 5.25 & & & \\
\hline & $24-26$ & 22 & 30.50 & 4.83 & & & \\
\hline & 27 and over & 13 & 32.53 & 4.52 & & & \\
\hline & Total & 177 & 29.76 & 5.08 & & & \\
\hline \multirow{5}{*}{$\begin{array}{l}\text { Charismatic } \\
\text { Leadership }\end{array}$} & $18-20$ & 56 & 30.12 & 5.87 & \multirow{5}{*}{$3-173$} & \multirow{5}{*}{.721} & \multirow{5}{*}{.541} \\
\hline & $21-23$ & 86 & 29.80 & 5.58 & & & \\
\hline & $24-26$ & 22 & 30.90 & 5.09 & & & \\
\hline & 27 and over & 13 & 32.00 & 4.77 & & & \\
\hline & Total & 177 & 30.20 & 5.55 & & & \\
\hline \multirow{5}{*}{$\begin{array}{l}\text { Leadership } \\
\text { Orientations Total }\end{array}$} & $18-20$ & 56 & 122.64 & 18.49 & \multirow{5}{*}{$3-173$} & \multirow{5}{*}{.459} & \multirow{5}{*}{.711} \\
\hline & $21-23$ & 86 & 122.12 & 18.61 & & & \\
\hline & 24-26 & 22 & 124.72 & 16.04 & & & \\
\hline & 27 and over & 13 & 127.92 & 16.35 & & & \\
\hline & Total & 177 & 123.03 & 18.04 & & & \\
\hline
\end{tabular}

When the One-Way Variance Analysis data in Table 5 is analyzed, it is determined that there is no significant difference $(\mathrm{p}>, 05)$ in the sub-dimensions of the scale and all scales according to the age variable. Also, when the total scores obtained from the scale are analyzed, it is determined that the participants who are 27 years old and above have higher leadership orientation levels than other participants.

Is there a significant difference in perceptions of the students of sports sciences' leadership orientation levels according to the place of residence? Oneway analysis of variance (Anova) results is given in Table 6 . 


\section{Hasan ULUKAN}

\section{Table 6}

Results of the One-way Variance Analysis Conducted to Students of Sport Sciences' Leadership Orientation Levels According to Place of Residence Variable

\begin{tabular}{|c|c|c|c|c|c|c|c|}
\hline & $\begin{array}{l}\text { Place of } \\
\text { Residence }\end{array}$ & $\mathbf{n}$ & $\overline{\mathbf{x}}$ & SD & df & $\mathbf{F}$ & $\mathbf{p}$ \\
\hline \multirow{4}{*}{$\begin{array}{l}\text { Human Resource } \\
\text { Leadership }\end{array}$} & Metropolis & 79 & 32.26 & 5.09 & \multirow{6}{*}{$3-173$} & \multirow{6}{*}{1.194} & \multirow{6}{*}{.129} \\
\hline & City & 61 & 31.13 & 5.17 & & & \\
\hline & County & 27 & 31.22 & 4.75 & & & \\
\hline & Village & 10 & 34.90 & 5.42 & & & \\
\hline \multirow{7}{*}{ Structural Leadership } & Total & 177 & 31.86 & 5.13 & & & \\
\hline & Metropolis & 79 & 31.40 & 4.64 & & & \\
\hline & City & 61 & 31.40 & 4.84 & \multirow{4}{*}{$3-173$} & \multirow{5}{*}{1.285} & \multirow{5}{*}{.281} \\
\hline & County & 27 & 29.70 & 4.06 & & & \\
\hline & Village & 10 & 32.50 & 4.92 & & & \\
\hline & Total & 177 & 31.20 & 4.66 & & & \\
\hline & Metropolis & 79 & 29.25 & 5.32 & \multirow{5}{*}{$3-173$} & & \\
\hline \multirow{3}{*}{$\begin{array}{l}\text { Transformational } \\
\text { Leadership }\end{array}$} & City & 61 & 30.16 & 4.78 & & \multirow{4}{*}{1.431} & \multirow{3}{*}{.235} \\
\hline & County & 27 & 29.33 & 4.66 & & & \\
\hline & Village & 10 & 32.50 & 5.68 & & & \\
\hline \multirow{6}{*}{ Charismatic Leadership } & Total & 177 & 29.76 & 5.08 & & & \multirow{6}{*}{.127} \\
\hline & Metropolis & 79 & 30.31 & 5.84 & \multirow{5}{*}{$3-173$} & \multirow{5}{*}{1.930} & \\
\hline & City & 61 & 30.09 & 5.49 & & & \\
\hline & County & 27 & 28.81 & 5.05 & & & \\
\hline & Village & 10 & 33.70 & 3.56 & & & \\
\hline & Total & 177 & 30.20 & 5.55 & & & \\
\hline \multirow{5}{*}{$\begin{array}{l}\text { Leadership Orientations } \\
\text { Total }\end{array}$} & Metropolis & 79 & 123.24 & 18.72 & \multirow{5}{*}{$3-173$} & \multirow{5}{*}{1.599} & \multirow{5}{*}{.191} \\
\hline & City & 61 & 122.80 & 17.70 & & & \\
\hline & County & 27 & 119.07 & 15.90 & & & \\
\hline & Village & 10 & 133.60 & 18.31 & & & \\
\hline & Total & 177 & 123.03 & 18.04 & & & \\
\hline
\end{tabular}

When the One-Way Variance Analysis data in Table 6 is analyzed, it is determined that there is no significant difference ( $p>.05)$ in the sub-dimensions of the scale and the whole scale according to the place variable where the resident 
Investigation of The Leadership Levels of University Students Who Do Sports and NonSports According to Different Variables: The Case of Isparta.

leadership orientation is located. Also, when looking at the total scores from the scale, it was determined that the level of leadership orientation of the people living in the village was higher than the other participants.

Is there a significant difference in perceptions of Students of Sport Sciences' leadership orientation levels according to the variable of active doing sports? To find an answer to the sub-problem, independent sample t-test results are given in Table 7.

\section{Table 7}

Results of the t-Test Analysis Conducted to Students of Sport Sciences' Leadership Orientation Levels According to Active Doing Sport Variable

\begin{tabular}{lccccccc}
\hline & $\begin{array}{c}\text { Active } \\
\text { Doing } \\
\text { Sport }\end{array}$ & $\mathbf{n}$ & $\overline{\mathbf{x}}$ & SD & $\mathbf{d f}$ & $\mathbf{t}$ & $\mathbf{p}$ \\
\hline Human Resource & Yes & 100 & 32.12 & 5.08 & 175 & .754 & .452 \\
Leadership & No & 77 & 31.53 & 5.20 & & & \\
Structural Leadership & Yes & 100 & 31.57 & 4.96 & & & \\
& No & 77 & 30.74 & 4.22 & & & \\
Transformational & Yes & 100 & 31.24 & 4.86 & 175 & 1.175 & .241 \\
Leadership & No & 77 & 27.84 & 4.74 & 175 & 4.656 & $\mathbf{. 0 0 0 *}$ \\
& Yes & 100 & 31.61 & 5.21 & & & \\
Charismatic Leadership & No & 77 & 28.37 & 5.49 & 175 & 3.998 & $\mathbf{. 0 0 0 *}$ \\
Leadership Orientations & Yes & 100 & 126.54 & 18.16 & & & \\
Total & No & 77 & 118.49 & 16.94 & 175 & 3.007 & $\mathbf{. 0 0 3 *}$ \\
\hline
\end{tabular}

When the Independent Samples t-Test in Table 8 is examined, "Transformational Leadership" $\left[\mathrm{t}_{(175)}=4.656, \mathrm{p}<, 05\right]$, "Charismatic Leadership" $\left[\mathrm{t}_{(175)}=3.998, \mathrm{p}<, 05\right]$ and $\left[\mathrm{t}_{(175)}=3.007, \mathrm{p}<, 05\right]$ significant differences were detected in the whole scale. According to the variable of active doing sports, it was determined that the participants were in favor of those active doing sports in their leadership orientation sub-dimensions and the total of the scale.

Is there a significant difference in perceptions of Students of Sport Sciences' leadership orientation levels according to the sports branch variable? One-way analysis of variance (ANOVA) results is given in Table 8 to find an answer to the sub-problem. 


\section{Hasan ULUKAN}

\section{Table 8}

Results of the One-way Variance Analysis Conducted to Students of Sport Sciences' Leadership Orientation Levels According to Type of Sport Variable

\begin{tabular}{llcccccc}
\hline & Type of Sport & $\mathbf{n}$ & $\overline{\mathbf{x}}$ & SD & $\mathbf{d f}$ & $\mathbf{F}$ & $\mathbf{p}$ \\
\hline \multirow{3}{*}{ Human Resource } & Team Sports & 72 & 32.04 & 4.85 & & & \\
Leadership & Individual Sports & 28 & 32.32 & 5.72 & $2-$ & .313 & .732 \\
& None of Them & 77 & 31.53 & 5.20 & 174 & & \\
& Total & 177 & 31.86 & 5.13 & & & \\
Structural & Team Sports & 72 & 31.26 & 5.15 & & & \\
Leadership & Individual Sports & 28 & 32.35 & 4.40 & $2-$ & \multirow{2}{*}{1.247} & .290 \\
& None of Them & 77 & 30.74 & 4.22 & 174 & & \\
Transformational & Total & 177 & 31.20 & 4.66 & & & \\
Leadership & Team Sports & 72 & 30.69 & 4.98 & & & \\
& Individual Sports & 28 & 32.64 & 4.30 & $2-$ & 12.658 & $\mathbf{. 0 0 0 *}$ \\
& None of Them & 77 & 27.84 & 4.74 & 174 & & \\
Charismatic & Total & 177 & 29.76 & 5.08 & & & \\
Leadership & Team Sports & 72 & 31.45 & 5.13 & & & \\
& Individual Sports & 28 & 32.00 & 5.47 & $2-$ & 8.059 & $\mathbf{. 0 0 0 *}$ \\
& None of Them & 77 & 28.37 & 5.49 & 174 & & \\
Leadership & Total & 177 & 30.20 & 5.55 & & & \\
Orientations Total & Team Sports & 72 & 125.45 & 18.10 & & & \\
& Individual Sports & 28 & 129.32 & 18.35 & $2-$ & \multirow{2}{*}{5.004} & $\mathbf{. 0 0 8 *}$ \\
& None of Them & 77 & 118.49 & 16.94 & 174 & & \\
\hline & Total & 177 & 123.03 & 18.04 & & & \\
\hline
\end{tabular}

When the One Way Variance Analysis in Table 9 is analyzed, among the perceptions of the participants regarding their leadership orientation levels, "Transformational Leadership" $\left[\mathrm{t}_{(2-174)}=12.658, \mathrm{p}<, 05\right], \quad$ "Charismatic Leadership" $\left[\mathrm{t}_{(2-174)}=8.059, \mathrm{p}<, 05\right]$ and $\left[\mathrm{t}_{(2-174)}=5.004, \mathrm{p}<, 05\right]$ significant differences were detected in the whole scale. According to the variable of doing sports, it was determined that the participants were in favor of those who do individual sports in their leadership orientation sub-dimensions and the total of the scale.

\section{DISCUSSION, CONCLUSION AND SUGGESTIONS}

When the study was examined, a total of 177 students, $41.2 \%$ women, and $58.8 \%$ of men participated in the study. The majority of the students (48.6\%) 
Investigation of The Leadership Levels of University Students Who Do Sports and NonSports According to Different Variables: The Case of Isparta.

according to the age variable are between 21-23 years old. It was seen that the majority of the participants (44.6\%) were metropolitan, and the sports high school (37.3\%) according to the high school variable they graduated from. When the variable of active doing sports of individuals was examined (56.5\%), it was found to be yes. Also, when the sports branch status of the individuals was examined, it was determined that some participated in team sports $(40.7 \%)$. Is there a significant difference in perceptions of Students of Sport Sciences' leadership orientation levels according to gender? Independent sample t-test results are given to find an answer to the subproblem.

There was a significant difference between the perceptions of the participants regarding their level of leadership orientation according to the "gender" variable, "Transformational Leadership", "Charismatic Leadership" and the whole scale. According to the gender variable, it was determined that the participants were in favor of men in the sub-dimensions of leadership orientations and the scale. In another study, it was asked to examine the leadership characteristics of physical education teachers conducted by Güllü and Arslan (2009) according to some demographic variables. As a result of the research, it was observed that there was no significant difference between the gender variable and the leadership orientation of physical education teachers. In the study conducted by Aygün (2018), when the leadership orientation sub-dimensions are analyzed according to the gender variable, it is seen that there is a significant difference between the leadership sub-dimension towards the human. When the study of Senger (2014) is analyzed, no significant difference was found between the scores that teachers received within the sub-dimensions of the leadership scale and the gender variable. In a different study, Kandemir (2017) examined the leadership styles of coaches working in different individual sports branches in Elazig province and saw that there was a significant difference in gender according to gender variable. This study supports our study. When One-Way Analysis of Variance data was analyzed, it was found that there was no significant difference in the sub-dimensions of the scale and the whole scale according to the age variable of the participants. Besides, when the total scores obtained from the scale are analyzed, it is determined that the participants who are 27 years old and above have higher leadership orientation levels than other participants. In a different study, Serin (2016) examined the leadership styles of boxing coaches and saw a significant difference in Democratic behavior between the age variable and leadership style. When One-Way Analysis of Variance data is analyzed, it is determined that there is no significant difference in the sub-dimensions of the scale and the whole scale according to the place of residence variable regarding the level of leadership orientation of the participants. Also, when looking at the 


\section{Hasan ULUKAN}

total scores from the scale, it was determined that the level of leadership orientation of the people living in the village was higher than the other participants. In another study, the leadership quality of students residing in city centers was found to be lower (Çetinkaya and İmamoğlu, 2018). When the Independent Samples t-Test was examined, there was a significant difference between the participants' perceptions of their level of leadership orientation according to the variable of "active doing sports", "Transformational Leadership," Charismatic Leadership "and the whole scale. According to the variable of active doing sports, it was determined that the participants were in favor of those active doing sports in their leadership orientation sub-dimensions and the total of the scale. Tiryaki (1996) determined that those who do sports in a study on Students of Sport Sciences' with and without athletes are more aggressive than those who do not.

When the analysis is analyzed, "Transformational Leadership "Charismatic Leadership" and significant difference in all scales were determined among the perceptions of the participants regarding their leadership orientation levels according to the variable of "sports branch". According to the variable of active doing sports, it was determined that the participants were in favor of those who do individual sports in their leadership orientation sub-dimensions and the total of the scale.

In a study by Ming-Feng Kao (2003), team unity and leadership behaviors in team sports and individual sports were compared and significant differences emerged. In a different study conducted by Dorak and Vurgun (2006), it was found that there was a significant relationship between the empathy levels of team athletes and team association levels, and as the empathy levels of athletes increased, the level of team association increased.

In the research conducted by Lindauer (2000), it was stated that the democratic behavior and positive feedback behavior scores preferred by the athletes who are interested in individual sports in their coaches are higher than the athletes doing team sports.

In line with this study: It has been determined that students who do sports and do not do sports show similar leadership orientations. According to the gender variable, it was determined that the participants were in favor of men in the sub-dimensions of leadership orientations and the scale. It was determined that there was no significant difference in the sub-dimensions of the scale and the whole scale according to the variable of age. Also, when the total scores obtained from the scale are analyzed, it is determined that the participants who are 27 years old and above have higher leadership orientation levels than other participants. It 
Investigation of The Leadership Levels of University Students Who Do Sports and NonSports According to Different Variables: The Case of Isparta.

has been determined that there is no significant difference in the sub-dimensions of the scale and the whole scale according to the place variable where the resident leadership orientation levels are located. When One-Way Analysis of Variance is analyzed, there is a significant difference between the perceptions of the participants regarding their level of leadership orientation according to the type of sport and sports variable "Transformational Leadership", "Charismatic Leadership" and the whole scale.

\section{Suggestions}

It is thought that it is necessary to increase the participation of sports educated students in artistic activities in increasing their leadership qualities. A new leadership scale can be developed based on similar research in the field. The relationship between athletes and coaches can be examined in terms of leadership characteristics. It is recommended to include more information that can increase leadership orientation in the given sports training. Studies similar to our study can be done for larger sample groups. Thus, more comprehensive findings regarding leadership orientations can be reached. In the lessons on the concept of leadership, discussions can be provided based on videos, reading texts, and experiences to expand the trainers' perspectives on the situations that will be used by leadership orientations. When the current literature and the results of this research are examined for later studies, it may be suggested to conduct new researches with different methodologies and samples on the subject.

\section{REFERENCES}

Aygün, M. (2018). The effect of emotional intelligence and leadership features of ice hockey players on their sports trait self-confidence. Ph.D. Thesis, Atatürk University Institute of Winter Sports and Sports Sciences, 41-85.

Baltaş, A. (2007). Team Work and Leadership From Change to the Future. Remzi Bookstore.

Baltaş, A. (2012). Managing in Turkish Culture Global Achievements with Local Values. Remzi Bookstore.

Baltaş, A. (2016). Managing in Turkish Culture Global Achievements with Local Values. Remzi Bookstore.

Biçer, T. (2008). Total Quality Management and Football Applications in Sports. Beyaz Yayınları. 


\section{Hasan ULUKAN}

Bolman, L. G \& Deal T. E. (1990). Leadership Orientations (self). Leadership Frameworks.

Brooks, I. (2006). Organizational Behavior: Individuals, Groups, and Organizations. Pearson Education.

Büyüköztürk, Ş. (2017). Data Analysis Handbook for Social Sciences Statistics, Research Pattern SPSS Applications, and Interpretation. Pegem Akademi Publications.

Büyüköztürk, Ş., Çakmak, E. K., Akgün, Ö. E., Karadeniz, Ş. \& Demirel, F. (2012). Methods of Scientific Research. Pegem Academy Publications.

Cengiz, R. \& Güllü, S. (2018). Investigation of Leadership Orientation and Physical Respectiveness Levels of Faculty of Sport Sciences Students. Gaziantep University Journal of Sport Science, 3(4), 94-108.

Çetinkaya, G. \& İmamoğlu, G. (2018). Research on Leadership Tendency of Students Taking Sports Education According to Difference Variations. The Journal of International Social Research, 11(19),719-725. Doi: 10.17719/ jisr.2018.2681

Daft, R. (2001). Organization Theory and Design. Thomson South-Western, Eighth Edition.

Daft, R. L. (1997). Management. 4th ed. Dryden Press.

Darbaz, T. (2004). Leadership in the $21^{\text {st }}$ Century. The International Leadership Symposium, Military Academy.

Dereli, M. (2003) A Survey Research of Leadership Styles of Elementary School Principals. Master Thesis, Middle East Technical University Educational Sciences, Science Department of Education.

Dorak, R. F. \& Vurgun, N. (2006). The Relation of Empathy and Team Cohesion in Terms of Team Sports. Ankara University Spormetre The Journal of Physical Education And Sport Sciences, 4, 73-77.

Eren, E. (2012). Organizational Behavior and Management Psychology $\left(13^{\text {th }}\right.$ Edition). Beta Publications.

Eren, E. (2013). Management and Organization. Contemporary and global approaches. Beta.

Erol, E. (2016). Management and Organization. Beta Publisher. 
Investigation of The Leadership Levels of University Students Who Do Sports and NonSports According to Different Variables: The Case of Isparta.

Ertürk, M. (1998). The Basic Principles of Business Science. (3 ${ }^{\text {rd }}$ Edition). Beta Publications.

Güllü, M. \& Arslan, C. (2009). Leadership styles of physical education teachers. Mustafa Kemal University Journal of Social Sciences Institute, 6(11), 353368.

Hesselbein, F., Goldsmith, M. \& Beckhard, R. (2000). The Leader of The Future (Translation: Hayrettin Tok). Form Publications.

Kandemir, D. (2017). Examination of Leadership Style of Coaches Serving Different Individual Sports Branches in Elazig Province. Master Thesis, Selcuk University, Institute of Health Sciences.

Karasar, N. (2012). Method of Scientific Research. Nobel Publication.

Karasar, N. (2016). Method of Scientific Research. Nobel Publication.

Karkın, N. (2004). Leadership behavior of public and private sector managers. A literature analysis experiment. Turkish Journal of Administration, 445, 4383.

Koçel, T. (2001). Management of The Business. ( ${ }^{\text {th }}$ Edition). Beta Edition.

Koruç, Z. (1995). Coach characteristics and coach personality in volleyball. The Journal of Volleyball Science and Technology, 3-9.

Lindauer, J. R. (2000). A Comparison of Preferred Leadership Behaviour of College Athletes in Individual and Team Sports. Unpublished master's thesis, University of Wisconsin-La Crosse.

McArdle, M. K. (2008) Leadership Orientations of Community College Presidents and the Administrators Who Report to Them: A frame analysis. University of Central Florida Orlando, dissertation for the degree of Doctor of Education.

Ming, F. K. (2003). Relationship Between Perceived Coach Leadership Behaviors and Team Cohesivenens Among Taiwanese Team and Individual Interscholastic Sports Participants. Unpublished doctoral dissertation, The University of Dakota.

Özdemir, E. (2003). Leadership and ethics. The Journal Economics and Administrative Sciences of Uludag University, 22(2), 151-168.

Robbins, S. (1984). Management: Concepts and Practices. Prentice-Hall.

Secer, I. (2015). Practical Data Analysis with Spss and Lisrel. Ani publishing. 


\section{Hasan ULUKAN}

Senger, K. (2014). Examination of Teachers' Perception of Leadership Orientation: The Case of Kars. Master thesis, The Institute of Social Sciences.

Serin, K. (2016). Determination of Leadership Styles of Boxing Trainers. Master thesis, Selcuk University Institution of Medical Sciences.

Tiryaki, Ş. (1996). Determination of aggression levels of individuals who do sports: A review in terms of team and individual sports. International Symposium of Sport Psychology, 10-12.

http://www.tdk.gov.tr/index.php?option=com_gts\&arama=gts\&guid=TDK.GTS $.5 c 8 \mathrm{e} 77 \mathrm{bfd} 0 \mathrm{~d} 136.19186088,23$ June 2019. 